\title{
Te Ara ō Rakimārie: The Pathway of Peaceful Living
}

\section{Abstract}

This paper traces the peacebuilding efforts of Anne Te Maihāora Dodds (Waitaha) in her North Otago community over the last twenty-five years. The purpose of this paper is to record these unique localized efforts, as an historical record of grass-roots initiatives aimed at creating a greater awareness of indigenous and environmental issues. It describes the retracing of ancestral footsteps of Te Heke Ōmaramataka (2012), the peace walk at Maungatī (2012) and the Ocean to Alps Celebration (1990). This paper also discusses the genesis behind cultural events such as Oamaru Stone Carving (2000), the short film entitled Tohu (2006), the dramatization of Te Maihāroa and Te Heke (2002) and the historically significant Waitaha Taoka (treasures) held within the Willets Family Artefacts Collection (1990). The accompanied whānau photographs present a visual snapshot of these experiences and provide a sense of the occasions. This paper is concluded with a brief synopsis of these peacebuilding activities, and the added richness to this rural community.

\section{Keywords:}

Waitaha, bicultural, rakimārie (peaceful living), peacebuilding, peaceful practices, collaboration. 


\section{Mihimihi}

Ko Rakinui rāua ko Papatūānuku, tēnā kōrua

Ko Aoraki te mauka

Ko Waitaki te awa

Ko Uruao te waka

Ko Rākaihautū te tipuna

Ko Waitaha rātou ko Kāàti Māmoe, ko Ngāti Rārua kāà iwi

Ko Te Maihāroa te whānau

Ko Bill Dodds tōku hoa rakatira

Ko Anne Sissie Pate Titaha Te Maihāroa-Dodds ahau

Anei he kākano tapu o Waitaha

Nō reira, tēnā koutou, tēnā koutou, tēnā koutou katoa

\section{Introduction}

This paper is documents the last twenty-five years of peacebuilding activities of Anne Sissie Pate Titaha Te Maihāroa Dodds within the rural town of Oamaru, North Otago. Anne is a direct descendant of Te Maihāroa, the last tohuka (expert priest) of $\mathrm{Te}$ Waipounamu (South Island) who called for Southern Māori to rally together in the late nineteenth century, against the sale of ancestral land to settlers and a foreign way of life (Elsmore, 1999; Mikaere, 1988; Beattie, 1939-1945). Like her Pōua (Great Grandfather), Anne has dedicated her life to working for and on behalf of Māori, in order to achieve tino rakatirataka (self-determination) and to promote the awareness of environmental issues through a mana whenua lens. This paper describes many of these events over the last twenty-five years and documents the effect that these efforts have had on individuals, organisations, the North Otago and Māori community that she has connections with.

\section{Kaupapa Māori}

The aim of this research was to record and preserve the body of history, cultural knowledge, values and wisdom that she holds 
so that it could be handed down to the next generation (Selby, 2005). It is written from an insider's perspective, as the writer is a niece of Anne, and deemed it important to document the peace-based activities that Anne contributes to her local and Māori community. This research draws on the framework of kaupapa Māori, for Māori by Māori, as the preferred research approach, because it (re)connects Māori ancestral and kinship ties through whakapapa and the Māori world (Bishop, 1996, 1998, 1999; Bishop and Berryman, 2008; Pihama, 2001; Smith, G. H., 1997, 2003; Smith, L. 1999). This methodology is valuable in the reclamation by Māori of tribal, hapū and whānau life histories, towards recapturing the rich cultural heritage and traditions (Selby and Laurie, 2005; Bishop, 1996).

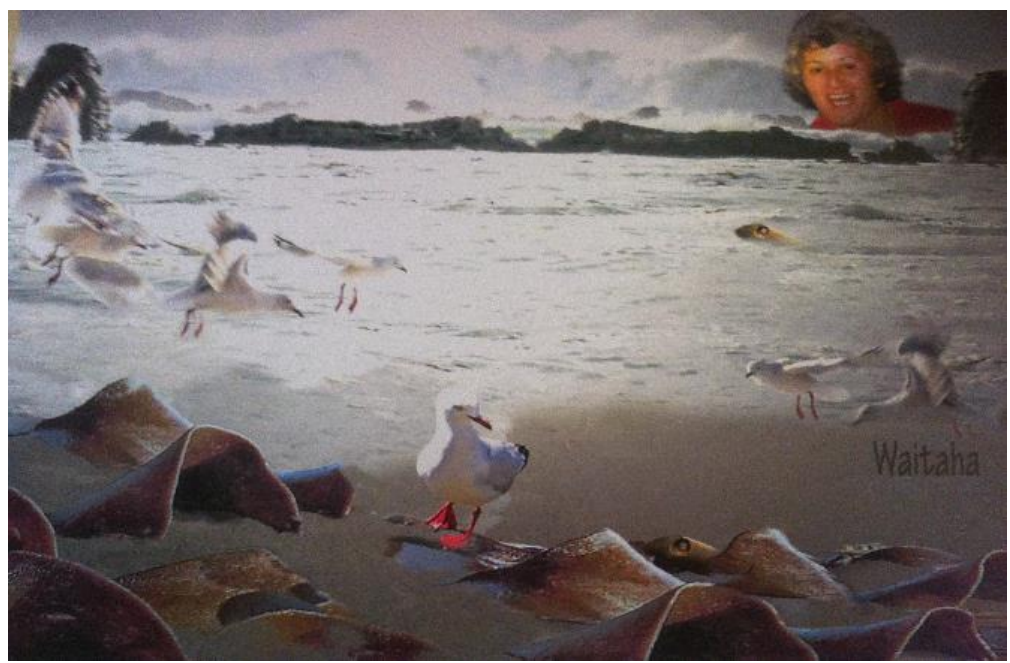

Photo one: Montage of Anne Sissie Pate Titaha Te MaihāroaDodds by Ramonda Te Maihāroa. Private collection Te MaihāroaDodds,A.

The kōrero with Anne took place at her home in Glenavy, North Otago, in April 2013. The scheduled 'interview as a chat' method (Bishop \& Berryman, 2008) was chosen, because it offered a 'natural setting' and is considered an appropriate way 
for indigenous people to share their stories and narratives. The process began with karakia, with Anne positioned in her favourite chair, surrounded by photos of her tūpuna and treasured pieces of pounamu. As Anne talked about the numerous events and activities that she has instigated and/or been involved with over the last twenty-five years, it became obvious that there was a particular focus on peace-building and bicultural relationships.

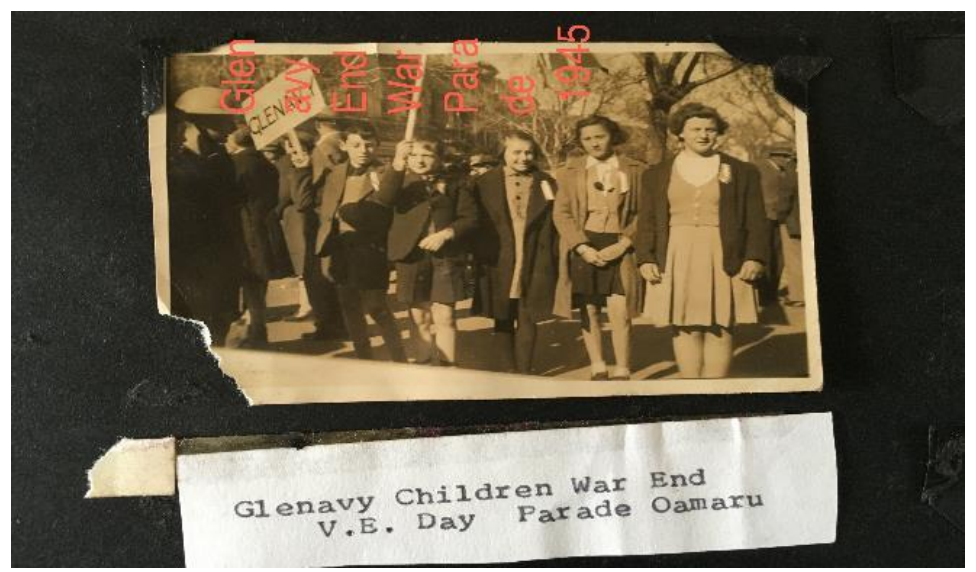

Photo two: Glenavy Children War End Day Parade Oamaru. Personal collection, Te Maihāroa-Dodds, A.

\section{Whakapapa}

Anne Sissie Pate Titaha Te Maihāroa was born in 1933, a home birth at Glenavy, in the Waitaki Valley, South Island of Aotearoa New Zealand. Whilst at the Ratana Pā on January 25 1937, in the presence of her parents Titi Kerikeri Gregory (Nō Moeraki) and Whakaririka (Sandy) Te Maihāroa (Nō Waiateruati), Anne was christened as a mōrehu by the Māori prophet T.W. Ratana himself, who also gave her ingoa as 'Pate Titaha Te Maihāroa, of the tribe of Waitaha, from Glenavy' (as recorded on her birth certificate). As mōrehu of the prophet Ratana, Te Maihāroa whānau have maintained a close relationship with the Ratana 
Church and Pā, as represented in the following photo, depicting Māori royal lineage in 1932.

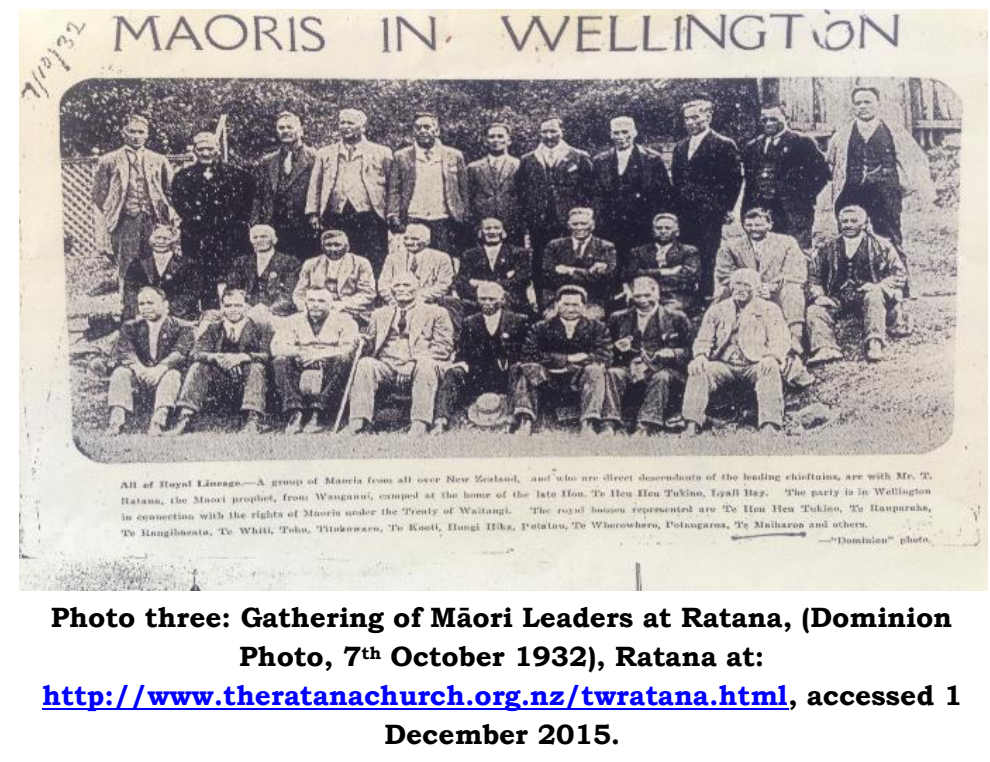

\section{He Kākano Tapu o Waitaha Sacred Seed of Waitaha}

Anne adds that her love for all people, aroha ki te tangata, derives from her happy childhood in North Otago and her lifelong marriage to Bill Dodds of 60 years. Anne Te MaihāroaDodds is highly respected and maintains close personal connections and friendships with the people that she meets of all races and religions. She states that it is 'tikanga' to embrace all new people to these lands. Anne vividly recalls her māmā telling her: "you are special, but no more special than the next person beside you". Her parents had fourteen children, twelve boys and two girls, but four brothers and her only sister had died prior to her birth. Anne sadly concedes that she is now the only one living of this generation, 'kei te mamae ahau' (I am in pain). 
Anne and her brothers have spent several decades striving for cultural recognition of Waitaha as a separate iwi, from the later arrivals of Kāâti Māmoe (15th century) and later Kāai Tahu (17th century), tribal people from the East Coast of the North Island. The introduction of the Ngāi Tahu Settlement Act (1988), resulted in Waitaha being included as a hapū of Ngāi Tahu, versus Waitaha as a separate and self-governing iwi (Te Maiharoa, Rangimarie and Te Maiharoa-Dodds, Anne Pate Sissie, Treaty of Waitangi Claim, MIR: 6215, 10th February, 2014). A driving force behind many of the performances, letters, submissions, and celebrations over the last thirty years, has been Waitahataka. Anne says that her brother, Rangimārie, put his whole heart and soul in to defending the mana of Waitaha. She recalls "What I understand from my Papa, is that from our WAITAHA Ariki line, my Great-Grandfather, Poua Te Maiharoa did not sign the Treaty. It is no wonder, as according to his belief system, we are of the whenua, the whenua does not belong to us". (Te Maihāroa-Dodds, A. Personal email communication. 27 February 2016). Ngāi Tahu have resisted any acknowledgement of Waitaha as a separate iwi, preferring Waitaha to be included under the Ngāi Tahu whanui umbrella.

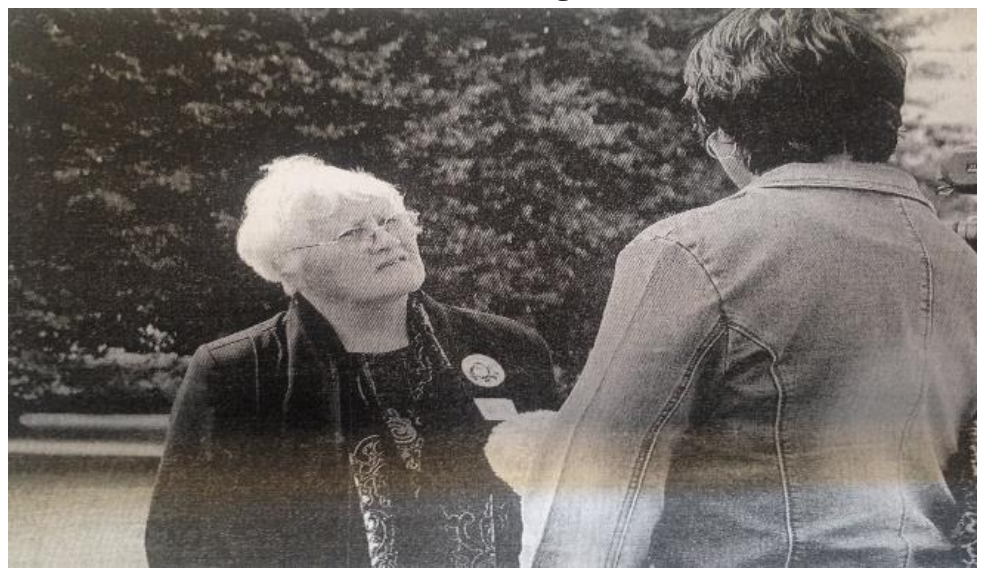

Photo four: Anne Te Maihāroa-Dodds being interviewed outside Parliament (2002). Personal collection Te Maihāroa-Dodds, A. 


\section{Community Service 1990-2015}

Indigenous Peoples throughout the world, handed down intergenerational knowledge by sharing and showing the younger generation how things are carried out. This paper set out to document Anne's peacebuilding efforts, in order to preserve the intellectual and cultural knowledge shared over one quarter of a century, but also as a signpost for the following generations to maintain and preserve this kaupapa. Whānau photographs accompany her kōrero, to provide a sense of these occasions.

\section{Ocean to Alps 1990}

Tribal traditions recall Aoraki as the tuakana of Tane Mahuta, where a fishing expedition went wrong, turning their waka upside down and the brothers to stone. As the eldest and tallest brother, Aoraki remains the tipuna mauka, from where the sacred waters of the Waitaki river flow to the sea. Symbolising the tears of Aoraki, the Waitaki river remains an integral symbol of tribal and cultural confirmation within the Waitaki Valley. The Ocean to Alps event (1990) was a significant occasion, which involved a journey up and down the Waitaki Valley to celebrate the 150 anniversary of the signing of Te Tiriti of Waitangi between Māori and the British Crown. Rangimārie Te Maihāroa was one of twelve appointed Commissioners for the 1990s Celebrations throughout Aotearoa and the Ocean to Alps event represented the spirit of partnership between the two Treaty of Waitangi partners, as Māori and the Crown participants, symbolically wove their way up the Waitaki Valley from the Waitaki River mouth to Aoraki.

Toku Awa, ko tōku Mana, Tōku Awa

Ko Tōku kaha, Tōku Awa, Ko tōku ora, Tōku Awa, Ko Tōku Wairua, Tōku Awa ko ahau!!

My river is my authority, my river is my strength, my river is my life 
My river is my spirit, I am the river and the river is me. Ko Waitaki toku Awa!!

(Te Maihāroa, A. June, 2015. Additional Evidence on 'Project Aqua - Waitaki River Low-Flow Trial').

The Ocean to Alps journey was undertaken from the sunrise of December $31^{\text {st }} 1989$ to sunset on $1^{\text {st }}$ January 1990. To honour this occasion, there were fifteen events planned along the journey, offering a multitude of sites for the community to participate in the celebrations (Timaru Herald, Dec 01, 1990). This trip started at the Waitaki River mouth, where a mōhiki, carried two special kohatu that had been selected from the Waitaki river, with the idea of placing one at the moraine, its founding source, with the other returned to Tasman Glacier to be positioned within the DOC building at Mount Cook Village. The mōkihi transferred the special stone to a jet boat, where a series of jet boats carried it up to be returned to the Tasman Glacier, and on to the base of Aoraki.

As part of the festivity and celebrations, a waka taua was transported down from Marlborough, to be paddled on Lake Pūkāki. Although the Tasman Glacier is separated from the flow of the Waitaki River, the journey was continued via two jet boats being lifted out of the Tasman Glacier by helicopter, and transported over to the base of Aoraki. A commemorative party was held that night, New Year's Eve 1989, which included staying at the Mount Cook Hermitage overnight, and celebrating alongside the two Commissioners Margaret Austin and Rangimārie Te Maihāroa.

\section{Oamaru Stone Carving Workshops 2000}

At the turn of the new millennium, Anne's artistic niece Ramonda Te Maihāroa, conceptualised the idea of taking the white Oamaru stone back into the Waitaki valley. This idea grew to include ten schools throughout the Waitaki Valley, where Anne and Ramonda, accompanied by Anne's brother 
Harry Te Maihāroa, ran Oamaru stone carving workshops for children. Georgie Salter, the then current Silver Ferns New Zealand netball coach, also supported by teaching the construction of manu aute workshops in the schools, incorporating the pūrākau of the giant pouākai. The symbol of the pouâkai quickly captured the imagination of the schools, followed on by Matariki Celebrations, where Anne and her theatrical friend Bronwyn, held dancing and singing workshops celebrating Matariki, the Waitaki River and harakeke. The tamariki subsequently adopted the cultural concept of kaitiakitaka, appreciating the sustainability of their natural surrounds by planting out the wetlands at the Mouth of the Wainakarua River to honour the river.

\section{Ancient Waitaha Treasures - Willets Family Collection 1990}

Celebrating one thousand years of Waitaha occupation, the Forrester Gallery in Oamaru held an exhibition from may 5 to June 3 1990, the ancient artefacts called "Ancient Waitaha Treasures' that had been recovered from Huruhuru Manu, an early kaika at the mouth of the Waitaki river. This exhibition was organised collaboratively with the museum, Te Maihāroa whānau (Waitaha), and the Willets family, who owned and farmed the land where the artefacts had been exposed from 1952 onwards, as a result of ploughing that land. The importance of this event was recognised by the opening blessing from Sir Paul Reeves, Governor-General and former Anglican Bishop. Also in attendance was the Ratana Band, whom had travelled over 800 kilometres to support this auspicious occasion. The exhibition also included Waitaha oral history, rock art and mōkihi. These artefacts remain on display today at the Oamaru Museum, catalogued under the Willets Family Collection. 


\section{Re-enactment of Te Maihāroa and Te Heke 2002}

The new millennium saw Anne, now in her 70's, infused with more energy, drive and passion for local activities and events. She had been in contact with writer and actress Tungia Baker from Levin, North Island, who was working in the South Island, asked she asked for a play script based on the re-enactment of Te Heke 1877. There was a delay in getting the script started, which was hurried along when Anne and her husband Bill went to visit Tungia, now living on the West Coast of the South Island. Anne gently stated "I don't care how long it takes, but we are not going home without it". Needless to say, Anne waited overnight for her beloved script, even though sadly, Tungia was unwell at the time. Her work was truly appreciated for finalising this play script during a challenging time.

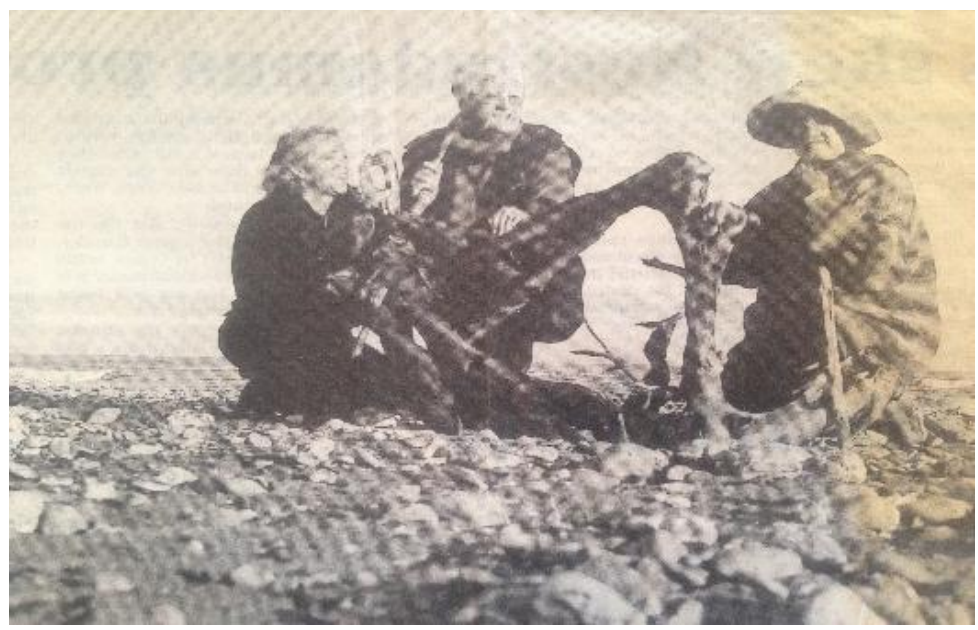

Photo five: Bronwyn Judge, Anne Te Maiharoa-Dodds and Tungia Baker, Haast Beach. Personal collection, Te Maihāroa-Dodds, A.

Tungia's play was performed on Waitangi Day 2002 at Elephant Rocks, a rock formation near Duntroon, depicting Te Maihāroa and Te Heke the to Ōmarama, with funding from Culture and Heritage, Creative New Zealand and donations from 
local businesses. Nannette Wright directed the play and the accomplished composer Dame Gillian Whitehead created an aria especially for this event, sung by Anne's niece, opera singer Ramonda Taleni Te Maihāroa. North Island actor Paki Cherrington narrated the drama, musically enhanced by taoka pūoro expert Richard Nunns. A Christchurch teacher, Gavin Britt designed and made the theatrical costumes and Aunty Kera, a tāua from Arowhenua attended along with local mayors and councillors. Tungia's words reflected on past historical events, but also about the dawning of a new age for Waitaha and the ancestral Waitaki River. The play was enjoyed by a large crowd of around six hundred people, who joined in with the festivities such as singing and dancing and (McKenzie, 2010). It was a multi-cultural event, with representatives from the Scottish, Philippine communities and many other culture groups. The Elephant Rocks performance was then invited to Christchurch to take part in the Festival of Romance.

Reflective of her inclusive nature, Anne had also invited other cultural groups and school children to be part of the celebrations. It was truly a community effort, with support from many areas. A commemorative $\mathrm{CD}$ was made entitled "Pakiwaitara o Te Pouakai, The legend of the wedge-tailed eagle: Te Heke o Te Maiharoa, Returning to ancestral land". This event was moving for many of the audience, with a Pākehā man coming up to Aunty after the re-enactment in tears, and saying that he had no idea that this history had unfolded within the valley that he lived. 


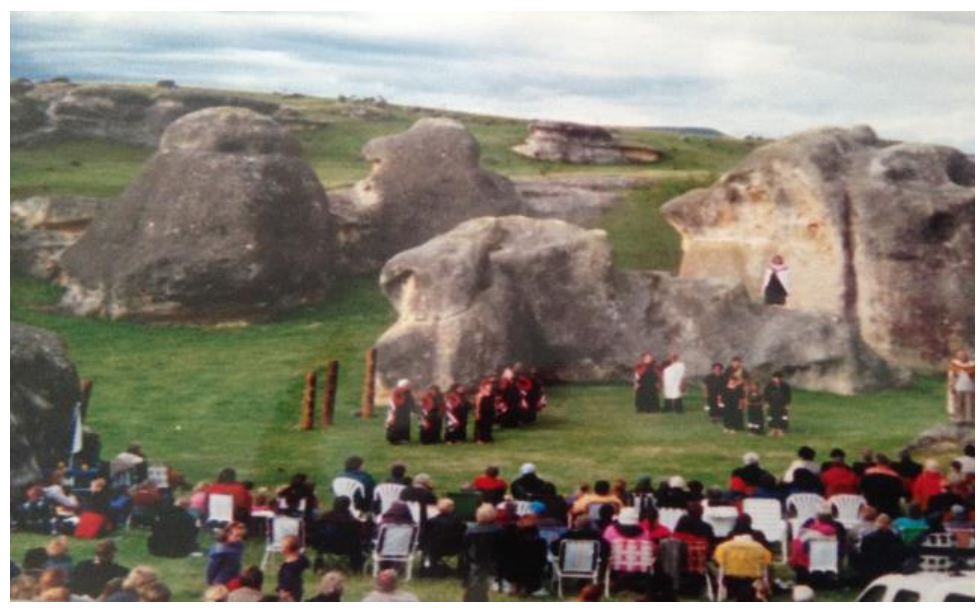

Photo six: Te Maihāroa and Te Heke play 2002, private collection, Te Maihāroa Dodds, $A$.

\section{Te Maihāroa Whānau Reunion December 2003}

In December 2003, the Te Maihāroa whānau, now spread wide and far across the globe, returned home to Waihao Marae for a whānau reunion. Some members travelled from their overseas homes as far away as Iceland. Over one hundred whānau attended the home-coming reunion and enjoyed four eventful days of reconnecting with each other, the marae and environment. Whilst much of the time was allocated to whakawhanaukataka, there were also cultural events such as gathering kai moana, learning about the art and craft of mōkihi and using supple jacks to make hīnaki. The evenings were spent learning about whakapapa, listening to the elders sharing kōrero and music, especially from the talented Te MaihāroaTaleni whānau, who are all competent singers and musicians. The opportunity to spend time together on a marae, enabled whānau to have a living relationship with our ancestral landscape and to strengthen whakapapa through renewed kinship ties. It provided the chance for whānau to sit with 
kaumātua, to hear first-hand the histories and tribal cultural practices of the Waitaha people.

\section{Project Aqua 2003-2005}

The new millennium also brought a new set of challenges for Waitaha. One of Anne's younger brothers who had always spoken up for the Waitaki River, Harry Te Maihāroa suddenly passed away in 2003, which meant that Anne assumed his place as a member of the Lower Waitaki River Management Society. Anne was also a member of the original Lower Waitaki Zone Committee which includes representatives from the three Ngāi Tahu Rūnanga. In 2003-2004 the Waitaki District Council called for submissions to determine the minimum flow required to protect the Waitaki River and to allocate water use, particularly for Meridian Energy's hydro dams. Concerned about the environmental impact on the mauri of the Waitaki River, Anne and Rangimārie both submitted an appeal against Project Aqua which was proposing a channel on the south side of the river. To reflect their high level of concern for the river, they also chose to raise these issues within their community through a peace march to honour the mauri of the awa.

Anne asked Transit New Zealand (responsible for operating and planning highways), for one lane of the Waitaki Bridge on State Highway One (SH 1) to be closed. Anne specifically stated that protest banners against damming the river would not be welcomed. State Highway One is the main trunk line stretching from the bottom of the South Island up to the top of the North Island. The men at the local Glenavy Tavern firmly agreed that State Highway One would never be closed, to which Anne's husband Bill Dodds replied "you don't know my wife!" (personal communication, Dodds, B. 13 April, 2013).

A dawn ceremony was undertaken, with Anne calling forward over 800 people who marched in silence to show resistance to Project Aqua. Accompanied only by resonances of pūtātara and the tapping of river-stones, sounds representing 
the chattering waters of the Waitaki River. Composer Gillian Whitehead (Ōtakou) wrote a duet for the river, sung by Ramonda Te Maihāroa Taleni and Anna Good from Dunedin. The march was carried out in complete silence along one closed lane of the Waitaki Bridge, led by a large masked pouākai. The pouākai dance with Ramonda Taleni and Anna Good sung Dame Gillian Whitehead's 'Waitaki Awa' Aria, composed especially by Gillian Whitehead for the Celebration on the Bridge. The Anne Harris School of Dance from Oamaru provided children for this and many other performances. People from all over the South Island came to support the Waitaki River and Anne's plea to not diminish the mauri of the awa. Anne was subsequently invited by David Parker to parliament to make a submission on behalf of the Waitaki River.

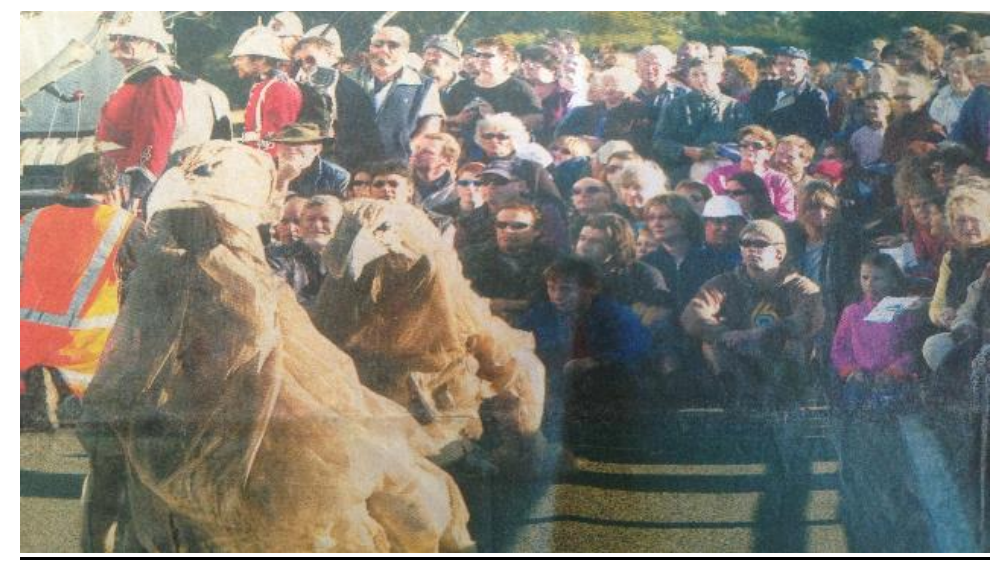

Photo seven: Celebration on the Waitaki Bridge. Personal collection, Te Maiharoa Dodds, A.

\section{Tohu 2006}

The loss of her precious younger brother, Harry Te Maihāroa in 2003, left Anne and her two remaining brothers, Tama and Rangimārie to continue their efforts to maintain the mana of the Waitaki River. About the same time, Bronwyn Judge was hiking in native bush when a golden kea made an appearance. Golden 
kea are extremely rare and protected under the Wildlife Act 1953 and Bronwyn interpreted her sighting of the bird as a tohu, representing the wairua of Harry Te Maihāroa and an omen of caution for the Waitaki River. As a proactive pacifist statement, Bronwyn in consultation and collaboration with Anne decided to make a film about the challenge besetting the Waitaki River, threading together the loss of Harry and the presence of the golden kea.

Bronwyn subsequently made a documentary in 2006 called 'Tohu', featuring the kea that had appeared earlier in 2004. Anne and her brother Tama were co-producers and gave an interview about their life growing up in their tribal rohe and their identity as Waitaha. The inaugural screening of the 'Tohu' film was held at Dunedin Art Gallery, where Mahara Okeroa, the Minister for Arts, Culture and Heritage, opened a special screening there for Matariki.

\section{Holcim Submission and Te Ana Raki 2007}

In 2007, Waitaha were notified through the Resource Management Act (1991) that the cement firm Holcim Holdings had lodged a claim to extract a larger quality of limestone from a small hill south of Oamaru. To Anne and Rangimārie, this equated to the disembowelment of a treasured Waitaha taniwhā at the site, known as Te Ana Raki. In their usual way, Anne and Rangi moved away from the negative focus of losing part of their puke, to raising the consciousness of the community to their natural surroundings by holding a celebration on top of Te Ana Raki to honour the whenua. Held on the site where Holcim were proposing further mining, Anne and Rangi invited their local community to a Waitangi Day 2008 celebration attended by several thousand. To honour the importance of the landscape, a recreation of Papatūānuku and Rakinui (Earth Mother and Sky Father) was re-enacted in 'Where Earth Meets the Sky' through music and dance, including the local rugby team representing as the children of the Atua, and Anne Harris 
School of Dance children portraying the flora and fauna of Aotearoa. The day also provided an opportunity for the community to get involved in kite making, where the day concluded with a hāngī and children flying giant kites. Occasions like this attract the local community to heighten their awareness of important environmental issue surrounding.

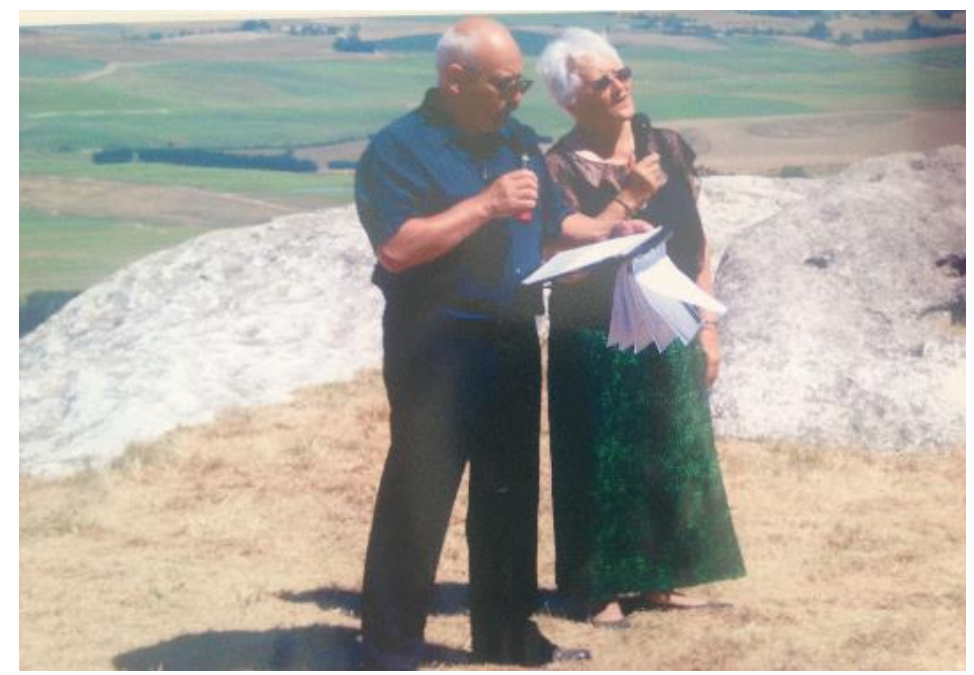

Photo eight: Te Ana Raki, Anne Te Maiharoa-Dodds and Alan Rakiraki. Personal collection Te Maihāroa-Dodds, A.

Anne and Rangimārie also made a submission on behalf of Waitaha concerning the Holcim Cement Holdings application. The Otago Regional Council and the Waitaki District Council approved it in February 2008, leading the Waiareka Preservation Society, Waitaki District Council and the Otago Regional Council to lodge an appeal against Holcim as the respondent. The Waiareka Preservation Society asked Anne Te Maihāroa to speak for them. Ngāi Tahu had originally opposed quarrying, but later came to an undisclosed arranged agreement and withdrew their countering submission. Judge Jackson heard the first Environmental Court hearing, followed 
by Judge Gordon Whiting, Commissioners Charles Mannind and deputy commissioner Dr Bruce Gollop (Otago Daily Times, Thursday, 14 May, 2009). Initially Judge Jackson challenged Anne's right to stand and speak on such matters, stating that Waitaha had "no formal standing" in the court, leading to Anne, Te Rūnganga o Ngāi Tahu (TRONT) and Moeraki rūnaka providing further supplementary affidavits.

As a result of these further submissions, Judge Whiting then ruled that more than one iwi could have mana whenua status for a rōhē and Anne could speak. Incredulous that an official court could treat her in such a dismissive way, Anne called for support from further afield, with Waitaha people coming from the North Island to support her claim. The extra time in Environmental Court resulted in extra legal expenses for Waitaha at a personal cost to Rangimārie and Anne Te Maihāroa. Ultimately Holcim won their case in the Environmental Court Hearing, but never actioned their plans. Anne was encouraged by the case in that she was given status to stand on behalf of her iwi and be heard in the Environmental Court.

\section{North Bank Tunnel Concept 2007-2010}

Project Aqua was abandoned in 2005, but was replaced in 2007 with the North Bank Tunnel Concept (2007-2010), a proposal to build a $34 \mathrm{~km}$ tunnel on the north bank of the Waitaki Dam to generate power and return the water downstream for the newly proposed large scale Hunter Downs Irrigation scheme. Anne and Rangi made a submission against the North Bank Tunnel application. Although they won many mitigating conditions from their submission, since the development of the North Bank Tunnel Scheme was stopped in 2013, none of the conditions that might have benefitted the Watiaha people, such as setting aside an area for mahika kai were required to be instigated. One outcome of these hearings is that Rangimārie and Anne were awarded the same standing conditions to 
Waitaha that were given to Ngāi Tahu, a significant acknowledgement of Waitaha as an iwi. There is now a proposal to lower the minimum flow of the river so that local farming irrigators can access more water. The present submission by Waitaha is that the current minimum flow should stay as it is regardless of irrigation demands (Judge, B. Personal email communication. 23 February 2016).

\section{Relationship Agreement between Waitaha and Waitaki District Council 2011}

It was during a meeting with the Waitaki District Council about the Waitaha Artefacts with Anne and her younger brother Tama Te Maihāroa, that one of the Councillors suggested that the council should have an Memorandum of Understanding with Waitaha. Although there was some on-going discussion about the formalising of this relationship, a Relationship Agreement was negotiated and signed by Rangimarie Te Maihāroa, as a sign of the significance of this partnership and in recognition of Waitaha as kaitiaki within this rōhē.

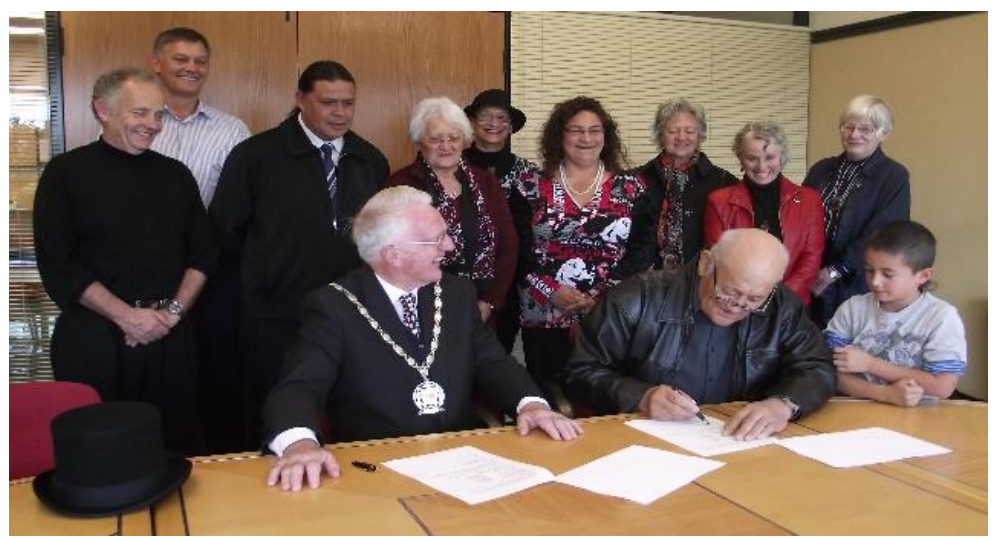

Photo nine: 'Significant milestone' for iwi, council Timaru Herald (23 April 2011). Waitaki District Council, permission granted. 


\section{Scott 1002012}

On Waitangi Day 2012, a concert in the Oamaru harbour to commemorate 100 years since the British explorer, Robin Falcon Scott left the bay bound for Antarctica in the Terra Nova. The Scott100 Celebrations saw the Navy HMS Otago moored in the harbour for the weekend, which Anne was invited onto and escorted around by the captain. A boating regatta was also supported by steam boats, yachts, mōkihi (reed boats) and a waka ama (outrigger canoe) from Puketeraki Marae. A Waitangi Day Concert was held in the evening outside in the Bay, with a song composed by Gillian Whitehead, written especially for Ramonda Te Maihāroa Taleni to sing. A dawn re-enactment, showed how Scott's men rowed in from the Terra Nova to telegraph the news of the polar party's fate to the world. There was a fund raising dinner for Scott100, which started with Anne performing the karaka at the pōwhiri for Hon. Chris Finlayson QC (Member of Parliament, Attorney-General of New Zealand), dances and Antarctic-themed entertainment. Although this event was primarily a Pākehā remembrance event, the inclusion and prominence of te ao Māori, reflects the bicultural relationships that Anne and others have developed and maintained within this flourishing community.

\section{Raknimārie Hikoi Peace Walks}

One of the most poignant events for Waitaha was Te Heke (The Migration), led by Pōua Te Maihāroa. As a protest against the ongoing Treaty of Waitangi breeches, and to distance southern Māori from contact with settlers, Te Maihāroa mobilised his people and led them to 'The Promised Land', settling on ancestral land at Ōmarama (Elsmore, 1999; Mikaere, 1988; Beattie, 1939-1945). Commemorative hikoi of Te Heke (187779 ) in the Waitaki Valley to honour and remember the deeds and wairua of Te Maihāroa and tīpuna, have occurred in 1927, 2012 and 2016. As discussed above, other celebrations include the Ocean to Alps Celebrations (1990) and the honouring the 
mauri of the Waitaki river (2004). The following Peace Walk at Maungatī (2012) and Te Heke Ōmaramataka (2012) are also examples of keeping the ahi kā alive.

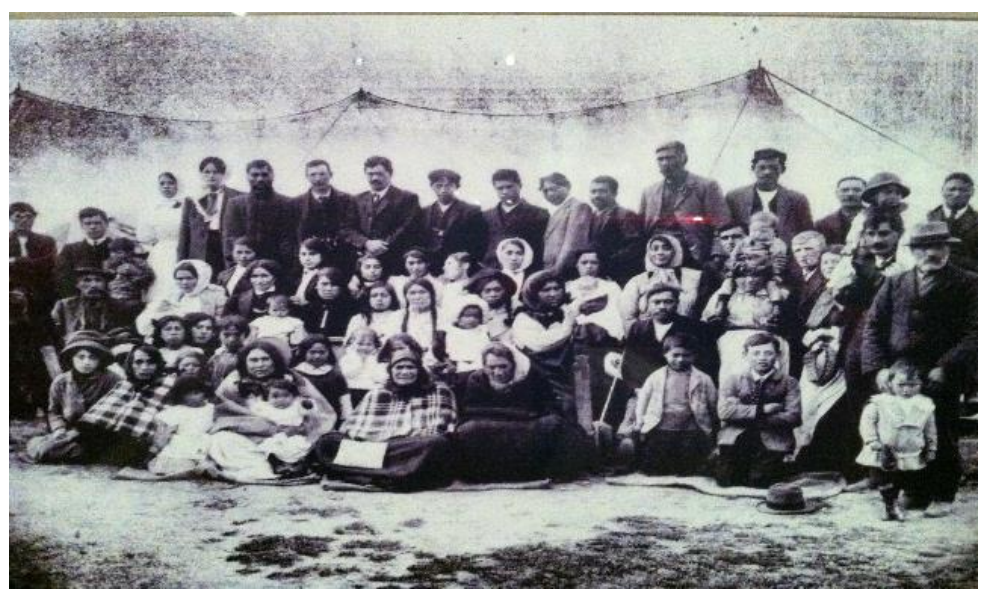

Photograph ten: Te Heke Commemoration 1927 at Morven. Te Maihāroa the prophet's daughter Tiriata Te Maihāroa is seated in the middle of the front row wearing tartan and son Taare Te Maihāroa standing wearing hat on left. Private collection, Te Maihāroa Dodds, A.

\section{Maungatī Peace Walk 2012}

For almost two decades, Sir Peter and Lady Fiona Elworthy, farm owners of Cleveland Maungatī in North Otago, have established and continue to have a close connection with Waitaha, as kaitiaki of the pouākai rock art. Although Sir Peter passed away in 2004, Lady Fiona remains an avid supporter of Waitaha and shared her vision to hold a peace celebration at Maungatī in 2012. Over one hundred people gathered, walking up a pathway lined with peonies, to the pouākai cave. The day was opened by Anne, with cousin Ken McAnergney sharing historical and cultural information with those that had gathered. This event was an expression of Lady Fiona's vision 
of bringing together diverse communities, with Waitaha as kaitiaki and the sharing the ancient cultural traditions.

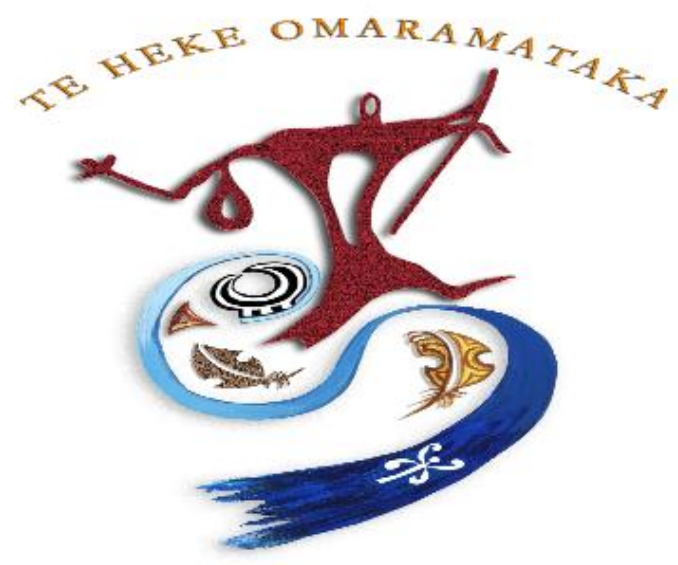

Photo 11: Te Heke Ōmaramataka 2012T-shirt design by Rua Pick. Permission granted, Pick, $R$.

\section{Te Heke Ōmaramataka 2012}

In April 2011, at the Waitaha Tai Whenua Trust Board Annual General Meeting (2011) held in Waimate, whānau expressed concern over the mauri of the Waitaki and a desire to commemorate 135 years since Pōua Te Maihāroa led his people on Te Heke (1877). The whānau agreed that these two take (topics) could be combined by revisiting the ancient sites in the Waitaki Valley to show gratitude to Papatūānuku and to pay homage to tipuna. The retracing of ancient ara (trails) is a traditional custom intricately linked with the cultural concept of ahi kā (burning of ancestral fires), through maintaining an on-going relationship with ancestral land. It also reflected the pacifist approach of Pōua Te Maihāroa, to remain connected to the surrounding landscape and assert the on-going tribal tenure of Waitaha. 
It was agreed that a contemporary heke would follow in the footsteps of the tūpuna from the mouth of the Waitaki River, through the Waitaki Valley to Te Ao Marama, meaning the place of light, commonly known today as Ōmarama. This event named Te Heke Ōmaramataka (2012) The Migration of Lingering Memories, involved up to 50 participants, walking 135 kilometres, representing one kilometre for each year since the original Te Heke left 135 years ago. This walk bought to life the cultural customs associated with such journeys and reconnected whānau with the whenua (land). A poroporoakī at the Ahuriri River concluded the journey, where the District Mayor and local farmer Mr Aubrey, apologised for the way their forbears had mis-treated Te Maihāroa and his people in the 1870 s.

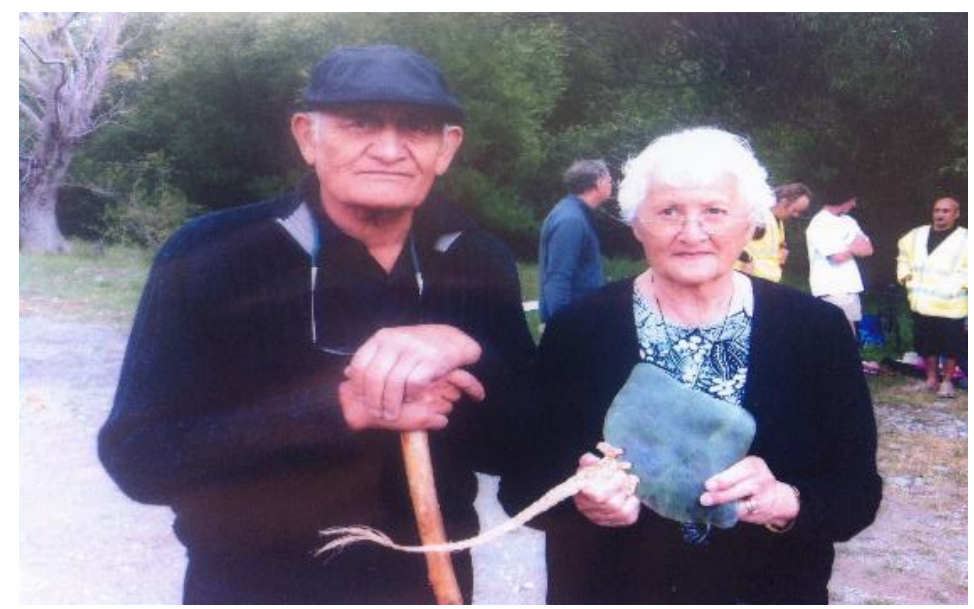

Photo 12: Rangimārie and Anne Te Maihāroa, Ahuriri River. December 2012. Private collection Te Maihāroa-Dodds, A.

\section{Korotuaheka Urupā 2014}

Another activity on Anne's wish-list is the restoration the ancient urupā at Korotuaheka kaika, on the southern edge of the Waitaki River Mouth, where Te Maihāroa, and his son Taare 
(Charlie) Te Maihāroa, along with other whānau are interred. Anne is thankful to Moeraki Rūnaka, who have also helped in locating tūpāpaku, using the latest geothermal imaging techniques. She reminds us 'what comes from Papatūānuku must also return to her' (Te Maihāroa, A., May, 2015). The Te Maihāroa whānau have also planted out the area in native plants assisted by a group of people serving community service on periodic detention. Anne hopes that the Waitaki District Council will one day recognise this wāhi tapu as being of historical importance as Te Maihāroa rests there and that access is supposed to be guaranteed via a paper road. Over nine thousand artefacts have also been sourced from the Korotuaheka and Huruhuru Manu area, which form part of the Willets Family Collection as seen in the North Otago Museum.

\section{Treaty of Waitangi Claim 2014}

The Treaty of Waitangi 1840 was taken to Takaroa, Ruapuke and then Ôtakou to be signed by the local chiefs. Anne noted that land negotiations after the signing of the Treaty of Waitangi were conducted by the more recent and larger Ngāi Tahu tribe, without invitation to the eldest tribe of Waitaha. In 1844, Ngāi Tahu sold eight million hectares to the New Zealand company for 2,000 pounds in 1848 (Mikaere, 1988). Anne understands that Pōua Te Maihāroa did not sign the Treaty because according to his belief systems, 'we are of the whenua, the whenua does not belong to us' (personal email communication, 27 February 2016).. Aunty asserts that it is:

... true tikanga, to stand in our own mana as WAITAHA, and not stand on another tribe, meaning Ngaitahu. We saw a different light, possibly the same whakaaro as Poua Te Maiharoa, not to sign the Treaty, which gives away our rights. Our brother (Rangimārie Te Maihāroa) spent endless time and money in the Court, and so the 
injustice continues on today, a year after his passing on April 2015, aged 84 years (Te Maihāroa, A. Personal email communication. 27 February 2016).

On the $10^{\text {th }}$ of February 2014 Rangimārie Te Maihāroa and Anne Pate Sissie Te Maihăroa-Dodds lodged a claim to the Waitangi Tribunal to seek leave to further amend an earlier claim MIR 6215 against the Crown relating to the loss of identity, lands and resources of the Kāti Ngāti Rakai, o Waiarki o aio Waitaha people (Te Maiharoa, R. \& Te Maiharoa-Dodds, A. Treaty of Waitangi claim, 10.02.2014:2). As this claim is before the Treaty Settlement Office, the details of the above claim remain undisclosed. Since the lodgement of this claim in February 2014, Rangimarie Te Maihāroa has since passed in April 2015.

Anne Pate Sissie Te Maiharoa-Dodds now waits patiently in her $83^{\text {rd }}$ year, for the Crown to address the Treaty breaches against her people. A similar plea to that made by Pōua Te Maihāroa in the mid to late nineteenth century to the Crown, Anne echoes his call to uphold the mana of the indigenous people and to protect and preserve the ancestral lands and customs. For Waitaha, an apology and cultural redress by the Crown would demonstrate respect of ancient sovereignty, so that unresolved grievances can be laid to rest and a shared future of peaceful co-habitation can realized. 


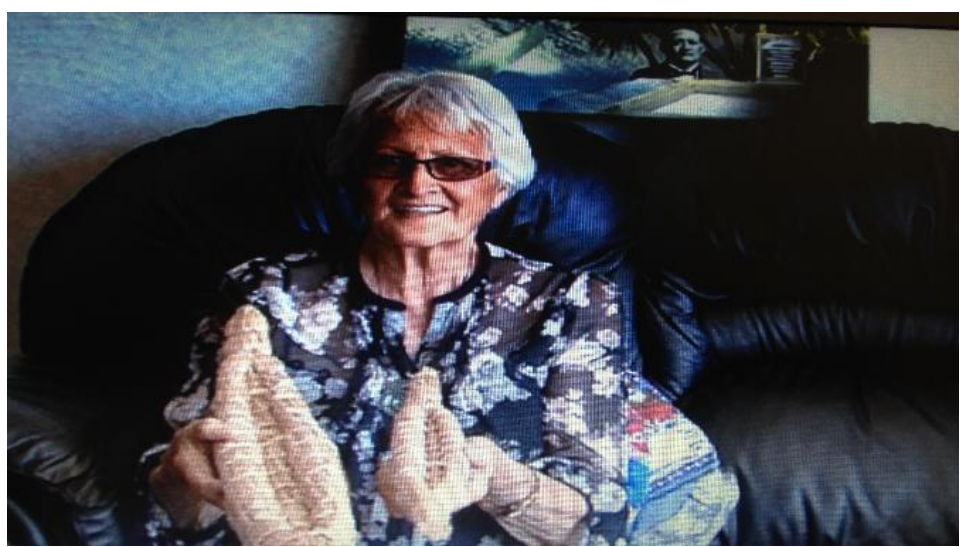

Photograph 13: Anne showing her miniature mōkihi. April 2014. Private collection Te Maihāroa Dodds, A.

\section{Conclusion}

These events and projects showcased within this article, highlight the potential that one person, in this case Anne Te Maihāroa-Dodds, can achieve when moved by wairua, passion, and commitment, to make a difference in this world. As these endeavours naturally unfolded during a semi informal interview, four overlapping and interwoven themes arose: peace based, bicultural approaches, cultural revitalisation and political interventions. Anne has spent her lifetime, dedicated to promoting Waitaha through peace based events, connecting not only whānau, hapū and iwi, but also the wider community, instilling harmony and goodwill. This includes commemorative events such the Ocean to Alps Celebration (1990) which observed one hundred and fifty years since the signing of the Treaty of Waitangi in 1840, the peace walks at Maungatī (2012) and retracing the ancestral footsteps on the trails of Te Heke Ōmaramataka (2012). Such occasions have the effect of drawing diverse communities together to create a feeling of kinship at a human level, often shedding differences to focus on positive shared experiences. These collective encounters 
include bicultural events such as Scott 100 (2012), Relationship Agreement with Waitaki District Council (2012), Oamaru Stone Carving (2000). All of these occasions position Anne Te Maihāroa-Dodds as an integral Treaty partner within her North Otago community, and reveal her commitment to build and maintain harmonious relationships and share her cultural expertise.

There have also been numerous cultural based events such as the documentary Tohu The Sign (2006), Te Maihāroa whānau reunion (2003), the dramatization of Te Maihāroa and Te Heke (2002) and the Willets Family Artefacts Collection (1990). These occasions contribute to the creative, vibrant, interconnected community of the Waitaki District, with some of these endeavours reaching and touching the lives of several generations and hundreds of people.

Equally significant are the events that are aimed at the political arena. Anne, along with the support of her brothers, family and friends, have advanced their concerns regarding cultural preservation and conservational issues at a local, regional and government level. This is proven through events such as the Waitaha Treaty of Waitangi Claim (2014), legal access to Korotuaheka urupā (2014), North Bank Tunnel (200709), Holcim Submission and Te Ana Raki celebration (2007) and Project Aqua and the Waitaki Bridge Dawn Ceremony (2004). Each of these measures mobilise people, whether it be whānau or empowering local citizens to form a collective voice about the future of their community. Anne Te Maihāroa-Dodds has effectively engaged communities through cultural events and connected them with a wider kaupapa (theme) of changing hearts and minds, one step at a time.

It is through events such as described within this paper, that members of the North Otago community people have come together to voice their collective vision for a brighter, more sustainable future. Anne Te Maihāroa-Dodds has effectively mobilized her local community to engage in conversations, cultural events and political alliances to 'become' change agents 
within their own communities, towards the change that they want to see in the world. These community building activities and events help shape relationships within the community through sharing views, voices, perspectives and experiences. This paper highlights the emancipatory power that can be achieved through a peaceful, inclusive, bicultural approach, drawing on the integral role of kaitiaki (stewardship) as a vehicle to achieve political awareness and seek justice redress.

Mariki noa te awa o Waitaki, he roimata na Aoraki

The Waitaki River flows freely as they are the tears of Aoraki

\section{Acknowledgement}

A special mihi to Anne Pate Sissie Te Maihāroa-Dodds for her generosity, time and spirit. I would also like to acknowledge Bronwyn Judge for her continual support and commitment to the kaupapa. 


\section{References}

Beattie, H. (1939-1945). The Heke to Omarama 1878: A Celebrated Migration which nearly let to fighting. Beatties Collection. (193945) E:21.

Beattie, H. (1939). TIKAO TALKS Traditions and Tales of the Canterbury Maoris. A.H. \& A.W. Reed: Wellington.

Bishop, R. (1996). Collaborative research stories: whakawhanaungatanga. Palmerston North: Dunmore Press.

Bishop, R. (1998). Freeing ourselves from neo-colonial domination in research: A Māori approach to creating knowledge (pp. 199-219). Qualitative Studies in Education, 11 (2).

Bishop, R. (1999). Kaupapa Māori Research: An indigenous approach to creating knowledge. In N. Robertson (ed.), Mãori and psychology: Research and practice - the proceedings of a symposium sponsored by the Māori psychology research unit (pp. 106). Hamilton: Māori and Psychology Research Unit.

Bishop, R and Berryman, M. (2006). Culture Speaks: Cultural relationships \& classroom learning. Wellington: Huia Publishers.

Elsmore, B. (1999). Mana from Heaven: A Century of Maori Prophets in New Zealand. Auckland: Reed.

Henry, E and Pene, H. (2001). Kaupapa Maori: Locating Indigenous Ontology, Epistemology and Methodology in the Academy. Sage Publications. http://org.sagepub.com/content/8/2/234

McKenzie, N. (2010). Rhythms of Water. Oamaru Print.

Mikaere, B. (1988). Te Maiharoa and the promised land. Reed: Auckland.

Pihama, L. (2001). Tîhei mauri ora: honouring our voices: mana wahine as a kaupapa Māori theoretical framework. Dissertation Research Space. Auckland.

Richmond, O. (2001). "A genealogy of peacemaking: the creation and re-creation of order". Alternatives: Global, Local, Political 26.3 (2001): 317+. Academic OneFile. Web. 11 June 2013.

Selby, R. and Laurie, AJ. (2005). Maori and Oral History: a collection. National Oral History Association of New Zealand.

Smith, G.H. (1997). The development of Kaupapa Māori: Theory and Praxis. Unpublished Ph.D. Thesis. University of Auckland.

Smith, G. (2003). Kaupapa Māori Theory: Theorizing Indigenous Transformation of Education and Schooling, Kaupapa Māori Symposium, NZARE/AARE Joint conference, Hyatt Hotel, Auckland, New Zealand.

Smith, L. (1999). De-colonizing methodology: research and indigenous peoples. London: Zed Books.

Te Maihāroa, A. June, 2015. Additional Evidence on "Project AquaWaitaki River Low-Flow Trial.

Te Maiharoa, Rangimarie and Te Maiharoa-Dodds, Anne Pate Sissie. (2014). Amended Statement of Claim of the Waitaha Taiwhenua o Waitaki Trust against the Crown relating to the loss of identity, lands and resources of the Kati/Ngati Rakai, o Waiariki a aio Waitaha People. MIR: 6215. 


\section{Personal Communication}

Dodds, A. to Te Maihāroa, K. (16. 05.2015 and 27.02.2016).

Dodds, B. 13 April 2013.

\section{Newspapers}

Harbour subdivision revived. Source URL (retrieved on 11/07/2016 14:36): http://www.odt.co.nz/regions/northotago/376795/harbour-subdivision-revived

Ancestral Journey Retraced. Source URL (retrieved on 12/07/2016 14:58):

http://www.odt.co.nz/regions/northotago/241065/ancestral-journey-retraced

\section{Internet sources:}

Judge, Brownyn on behalf of Waitaha Iwi (Manawhenua) 2008: http://www.orc.govt.nz/Documents/Publications/Regional/R PS/Evidence/54\%20Waitaha\%20Iwi\%20evidence.pdf (accessed 03.02.2016).

Ministry of Business, Innovation \& Employment (2015). Mbie.govt.nz (accessed 03.02.2016).

Otago Daily Times. Extra cement production not needed, hearing told, by David Bruce on Thursday, 14 May, 2009.

Ngā Wāhi - Treaty Signing Occasions', URL (retrieved on 11/07/2016 2.52): http//www.nzhistory.net.nz/politics/treaty/nga-wahisigning-occassions, (Ministry for Culture and Heritage), updated 24-Sep-2015

\section{Photographs:}

Photo one: Montage of Anne Te Maihāroa-Dodds by Ramonda Te Maihāroa. Private collection Te Maihāroa Dodds, A.

Photo two: Glenavy Children War End Day Parade Oamaru, Personal collection, Te Maihāroa Dodds, A.

Photo three: Gathering of Maori Leaders 1932, Maori leaders from around New Zealand, who are direct descendants of the leading chieftains, gathered to support Ratana. They were camped at the home of the late Hon Mr Te Heu Heu Tukino at Lyall Bay. They were in Wellington in connection with the rights for Maori under the Treaty of Waitangi. They were a royal list of descendants who were present at the house Te Heu Heu Tukino, descendants from Te Rauparaha, Te Rangihaeata, Te Whitu Tohu, Titokowaru, Te Kooti, Honi Heka, Patau, Te Wheto Whero, Potangaroa, Te Maiharoa and others were gathered to support T.W. Ratana and ratification for the Treaty of Waitangi (Dominion Photo, $7^{\text {th }}$ October 1932), Ratana at: http://www.theratanachurch.org.nz/twratana.html, accessed 1 December 2015. 
Photo four: Anne Te Maihāroa Dodds being interviewed outside Parliament, 2002. Personal collection Te Maihāroa Dodds, A.

Photo five: Bronwyn Judge, Anne Te Maiharoa Dodds and Tungia Baker. Personal collection Te Maihāroa Dodds, A.

Photo six: Te Maihāroa and Te Heke play 2002. Private collection, Te Maihāroa Dodds, A.

Photo seven: Celebration on the Waitaki Bridge. Personal collection, Te Maihāroa Dodds, A.

Photo eight: Te Ana Raki, Anne Te Maiharoa Dodds and Alan Rakiraki. Personal collection Te Maihāroa Dodds, A.

Photo nine: 'Significant milestone' for iwi, council Timaru Herald (23 April 2011). Waitaki District Council, permission granted.

Photograph 10: Te Heke Commemoration 1927 at Morven. Te Maihāroa the prophet's daughter Tiriata Te Maihāroa is seated in the middle of the front row wearing tartan and son Taare Te Maihāroa standing wearing hat on left. Private collection, Te Maihāroa Dodds, A.

Photo 11: Te Heke Ōmaramataka 2012T-shirt design by Rua Pick. Permission granted, Pick, R.

Photo 12: Rangimārie and Anne Te Maihāroa, Ahuriri River. December 2012. Private collection Te Maihāroa-Dodds, A.

Photograph 13: Anne showing her miniature mōkihi. April 2014. Private collection Te Maihāroa Dodds, A. 


\section{Glossary}

ara

aroha ki te tangata

ahi kā

ariki

Atua

hākari

hāngī

harakeke

hīkoi

hīnaki

Huruhurumanu

hui

ingoa

kaika

kai moana

kaitiaki

kaitiakitaka

karaka

karakia

Kāti / Ngāti Rākai

Kāti Māmoe

kaumātua

kei te mamae ahau

kōauau

kōhatu

manu aute

Matariki

mihiwhakatau

mahika kai

mana

mana whenua

Maungatī

mauri

moemoeā

Moeraki

mōkihi

path/ pathway

love to the people

ancestral burning fires

high born

Gods

traditional feast

earth oven

flax

walk

net

ancient village

meeting

name

village

seafood

guardian

guardianship

welcoming call

prayer, incantation

sub tribe

$15^{\text {th }}$ century tribe

Māori elder

I am in pain

Māori musical instrument

stone

Māori kite

Māori New Year

Māori formal welcome

traditional food sources

prestige

people who hold the spiritual prestige

North Canterbury place

life force

dream, vision

Coastal village North Otago

reed boat

mōrehu

follower

Ngāi / Kāi Tahu

$17^{\text {th }}$ century tribe

Ngāi Tahu Rūnanga

Tribal Council

Oamaru

Ōmarama

north Otago town

inland town

peninsula near Dunedin city

earth mother

Papatūānuku

piopio

pōua

pouākai

pōwhiri

puke

oyster catcher

grandfather

ancient eagle

formal welcome

hill 
pūkāki

pūrākau

pūtātara

rakimārie

Rakinui

rōhē

Rūnake / Rūnanga

takiwā

tamariki

taniwhā

taoka pūoro

tāua

Tau iwi

Tane Mahuta

Te ao Māori

Te Heke

Te Heke Ōmaramataka

Te Rūnanga o Ngāi Tahu

Te Waiateruati

tikaka / Tikanga

tipuna mauka

tohu

tuakana

tūpāpaku

urupā

waka

waharoa

wāhi tapu

waka ama

waka taua

waiata

Waihao Marae

Waimate

wairua

wāhi tapu

whakapapa

whakawhanaukataka

whaikōrero

whenua inland lake

legends

conch shell trumpet

peaceful living

sky father

tribal area

local tribal council

area, region

children

guardian

musical instruments

grandmother

Non Māori

god of the forest

Māori worldview

The migration

The migration of rememberance

Statutory body of Ngāi Tahu

Old South Canterbury village

customary protocols

ancestral mountain

sign

elder

deceased

ancestral burial ground

canoe

gateway

sacred area

outrigger canoe

warrior canoe

song

tribal meeting house

South Canterbury town

spirit

sacred site

genealogy

building relationships

welcoming speeches

land 